\title{
SUSTAINABILITY IN EDUCATION: AN EVALUATION OF A NEW TEACHING AND LEARNING STRATEGY IN CHARTERED ACCOUNTANCY STUDIES - A STUDENT PERSPECTIVE
}

\author{
Riëtte de Lange* \\ University of Johannesburg \\ riettedl@uj.ac.za \\ Ben Marx \# \\ University of Johannesburg \\ benm@uj.ac.za \\ Alex van der Watt+ \\ University of Johannesburg \\ alexvdw@pps.co.za
}

Received: April 2013

Accepted: June 2013

\begin{abstract}
Sustainability has been described as the primary moral and economic imperative of the twenty-first century and one of the most important sources of both opportunities and risks for businesses. From an educational perspective, sustainability could be related to enhancing accurate, reliable and relevant teaching and learning in an ever-changing and evolving educational, economic and social landscape. The objective of the paper is twofold: it aims, firstly, to provide a brief overview of the higher education landscape and drivers for change in accounting education and the need for sustainable teaching and learning; and, secondly, it aims to provide evidence of the implementation of a new teaching and learning strategy in accountancy education programmes at a large SAICAaccredited residential higher education institution. This was done through a literature review and supported by empirical evidence obtained from questionnaires completed by the honours student group in chartered accountancy of the stated institution. The study found that, although initially new to students, the teaching and learning approach was well accepted and eventually created an environment conducive to teaching and learning. It was also found that students marks improved, which resulted in higher throughput rates.
\end{abstract}

Keywords

Accounting education; Competency framework; Sustainability; Student evaluation of teaching and learning; Lifelong learning; Learning to be; Learning to become

*Dr Riëtte de Lange is Director: Research, Monitoring and Benchmarking, University of Johannesburg, South Africa

\#Prof Ben Marx is Head of Auditing, Department of Accountancy, University of Johannesburg, South Africa.

+Prof Alex van der Watt is Head of the Department of Accountancy, University of Johannesburg, South Africa. 


\section{INTRODUCTION}

Sustainability is the capacity to endure, and has been described as the primary moral and economic imperative of the twenty-first century and one of the most important sources of both opportunities and risks for business. Modern organisations should try to conduct their business in a manner that meets existing needs without compromising the ability of future generations to meet their needs. Thus organisations are expected to behave like responsible corporate citizens (Institute of Directors (hereafter loD), 2009; Marx \& Van Dyk, 2011). Higher education institutions (hereafter $\mathrm{HEls}$ ) have been recognised as key institutions that can contribute to the vision of a global sustainable future through research and teaching, and by acting as models of sustainability in their own domains (Priddy \& Bailey, 2011; Wright, 2009).

HEls face many challenges that impact on their ability to providing quality teaching and learning. Such factors include: student under-preparedness due to inadequate school education (among other reasons), a diverse student population, with many coming from disadvantaged educational backgrounds, poor success outcomes, demand for greater access to higher education, institutional capacity constraints, increased emphasis on research, quality assurance expectations, globalisation, rapid development in information technology, the quest for market orientation and customer-centred operations, increasingly complex legal environments, funding and resources constraints, as well as the growth in local and international providers of private higher education (Barac, Marx \& Moloi, 2011; ClarenceFincham \& Naidoo, 2011; Council for Higher Education (hereafter CHE), 2007, 2009a). HEls also carry substantial economic weight and are fulfilling many occupational roles that involve various stakeholders (Küpper, 2003). In South Africa HEls have the additional responsibility of playing a critical role in restoring the imbalances inherited from the apartheid era (Hall, Symes \& Luescher, 2002; Kulati 2000; CHE, 2009b), and according to the Ministerial Statement of Higher Education Funding (hereafter MoE) (2006/7 to 2008/9) (MoE, 2009) should make major contributions to the social transformation of South African society and stimulate national economic growth and development. Through their student admissions and teaching and learning activities $\mathrm{HEls}$ could assist with the creation of a fairer and more just society for South Africa (CHE, 2009b; MoE, 2009; PricewaterhouseCoopers, 2009).

From a higher education perspective, sustainability could be related to providing accurate, reliable, relevant and meaningful teaching and learning in an ever-changing and evolving educational, economic and social landscape. Accordingly, there is a need for a strategy of teaching and learning that takes cognisance of the changing external environment and student circumstances, backgrounds and expectations. Such a strategy of teaching and learning should foster an environment of real-world education that creates sustainable learning and value for generations to come. This requires a shift away from a knowledge-based teaching approach to developing students who are capable of learning to learn (which is also referred to as learning about, learning to be, or learning to become) - that is, developing skills that will prepare accounting graduates for lifelong learning (Adler \& Milne, 1995; Agyemang \& Unerman, 1998; Barnett, 2009; CHE, 2010; Clarence-Fincham \& Naidoo, 2011; De Lange, Jackling \& Gut, 2006). It is therefore essential that $\mathrm{HEls}$ offer programmes that are of the highest quality and that meet the needs of their various stakeholder groupings to ensure the relevance and sustainability of the institution. This also applies to the HEls' Departments of Accountancy which are offering the South African Institute of Chartered Accountants (hereafter SAICA) accredited programmes. 
To date, little research has been done on appropriate and effective teaching and learning strategies and the practices within the accounting programmes offered by the SAICA-accredited HEIs (as required by the SAICA Competency Framework (SAICA, 2010)), as is evident from a search of the relevant accounting education literature in South Africa (cf. journals such as: Journal of Economic \& Financial Sciences; Meditari Accountancy Research, SA Journal of Accounting Research) and academic databases (cf. Nexus Database System; ProQuest, National Research Foundation and Google Scholar). Given the requirements of the Competency Framework and the need for Departments of Accountancy to offer teaching and learning that fosters a meaningful learning environment of real-world education in order to create sustainable learning and value for generations to come, research in this regard, and supported by empirical evidence, is essential. The remainder of this paper is organised as follows: the next section presents the objectives, scope and limitations of the study. The sections that follow describe the theoretical framework of the paper, the methodology applied and the empirical findings and deductions. Conclusions and recommendations drawn from the study and areas identified for future research are presented in the last section.

\section{OBJECTIVES, SCOPE AND LIMITATIONS}

The objective of the paper is twofold: it aims, firstly, to provide a brief overview of the higher education landscape, the need for sustainable teaching and learning and the drivers for change in accounting education; and, secondly, it aims to provide evidence of the development and effective implementation of a new teaching and learning strategy in accountancy education programmes at a large SAICA-accredited residential $\mathrm{HEl}$.

This was done through a literature review and supported by empirical evidence obtained from questionnaires completed by the honours student group in chartered accountancy of the stated institution. The study has two specific limitations: firstly, the focus is on the higher education of prospective chartered accountants (hereafter CAs) and those accountancy departments accredited by SAICA, and, accordingly, the findings might not necessarily be representative of the practices at non-SAICA-accredited HEls, accounting education in general, or for other professional accounting bodies; and, secondly, the empirical evidence might not be reflective of other residential or non-residential SAICA-accredited HEls. However, as explained in section 3.1, the SAICA requires adherence to its Competency Framework (SAICA, 2010), and provides detailed guidance to the academic programmes. The findings of the study should therefore be of relevance to all such accredited $\mathrm{HEls}$.

\section{THEORETICAL FRAMEWORK}

\subsection{Higher education landscape}

Globally, the higher education sector is faced with many challenges, such as market pressures, reduced government funding, globalisation and other challenges as discussed in section 1 . This emphasises the need for HEls to offer quality teaching and learning that is relevant and that will be sustainable in the long term. There is also recognition of the need to equip graduates with a range of capabilities that will enable them to deal not only with employability, but also with global issues and the development of civic awareness and responsibility (Moir, 2011). South Africa's HEls are faced with further challenges such as the legacy of the apartheid schooling 
system, students coming from various educational backgrounds and cultures, language barriers and the pressure on success rates (Clarence-Fincham \& Naidoo, 2011; Council for Higher Education 2007).

The traditional education philosophy of teaching knowledge rather than skills has also come under intense scrutiny in the last number of years, globally as well as in South Africa, and this has resulted in a shift away from the concept of 'teaching' to that of the 'facilitation of learning' (Barnett, 2009; Jarvis, 2011). Accordingly, students must become members of a learning society, that is, learners who: have a repertoire of cognitive learning strategies, can function on a metacognitive level in respect of learning and themselves as learners, are motivated to learn, and can manage their feelings and available resources effectively (De la Harpe \& Radloff, 2000; McKenzie \& Wurzburg, 1997). This is described by the Association of American Colleges and Universities as providing educational environments that foster a wellgrounded intellectual resilience, a disposition towards life-long learning, and an acceptance of responsibility for the ethical consequences of their ideas and actions (Mayhew, Wolniak \& Pascarella, 2008). The European Commission is of the opinion that the scale of current economic and social change, the rapid transition to a knowledge-based society and demographic pressures resulting from an ageing population in Europe are all challenges which demand a new approach to education and training within the framework of lifelong learning (European Commission, 2007).

The South African higher education sector has over the years been subjected to many political and socio-cultural issues and developments that played a role in the formation and structuring of its landscape. These included the medium of instruction, which led to a split between Englishand Afrikaans-medium HEls, followed by sharp divisions along racial and ethnic lines. The challenge for the democratic government that came to power in 1994 was to recreate this higher education and training system into a single equitable system of quality education with a lifelong learning orientation (Walters, 2006; 2010). Accordingly, the focus was on restructuring the higher education landscape to achieve an integrated, unified higher education system based on the principles of equity, democratisation, quality, academic freedom, institutional autonomy, effectiveness and efficiency (Smout \& Stephenson, 2002). This was further supported by the "National Plan for Higher Education" published in 2001 by the Department of Higher Education, which set out the purposes of higher education as being: human resource development, highlevel skills training and the production, acquisition and application of new knowledge (CHE, 2009a; CHE, 2010; Barac, Marx \& Moloi, 2011; Marx, Barac, 2012). Since 1994 there has been increased participation in the higher education sector from students of various backgrounds, cultures, races and language groupings, and today South Africa boasts a vibrant higher education sector that provides world-class tuition and research opportunities through its 23 universities, universities of technology and many colleges (Smit, 2012; Marx, 2007). The University of Johannesburg (hereafter $\mathrm{UJ}$ ), whose Department of Accountancy is the focus of the study, is a large comprehensive higher education institution founded in 2005, and presently has more than 50000 students located on four campuses (Clarence-Fincham \& Naidoo, 2011).

In South Africa SAICA assumes a very direct responsibility for the education and training of CAs. In its role as Education and Training Quality Assurer, SAICA accredits certain academic programmes that are specifically designed to allow access to Part I of the Qualifying Examination. Accreditation of a programme by SAICA means that the academic unit has put in place the appropriate resources that, if utilised effectively, should enable it to deliver the programme at the required standard and level of quality, and further that the programme meets SAICA's requirements in terms of the standards of learning and teaching (SAICA, 2010; Marx \& 
Van der Watt, 2013). Currently, there are 15 SAICA-accredited HEls in South Africa (SAICA, 2012). The Department of Accountancy's programme at $U J$ is one of the programmes accredited by SAICA.

\subsection{Sustainability in chartered accounting programmes}

For higher education institutions to be sustainable in the modern era they are required to understand and explore the opportunities of a changing society and new world dynamics while being proactive in responding to the risks involved. This will require that they understand and respond to the challenges facing the higher education sector, as well as the needs of their stakeholders.

Accounting can be described as a discipline that covers many subject areas and different disciplines and the teaching thereof in the higher education sector occurs at various institutions, both public and private, and is often regulated by designated accounting bodies. For accounting education programmes to be sustainable in the long run, accurate, reliable and relevant teaching and facilitation of learning should be provided that meets the requirements of the ever-changing and evolving educational, economic and social landscape. Departments of Accountancy should therefore reflect on an on-going basis on how effective their teaching and learning philosophy and teaching and learning strategy are. This is what is happening in the Department of Accountancy at UJ, as explained in section 3.6, and it is the focus of the empirical study in section 5 .

\subsection{Drivers for change in CA studies}

There are many factors and circumstances that affect $\mathrm{HEls}$ programmes in general, and accounting studies specifically. Drivers for change in the education programmes for chartered accountancy studies in recent years include:

\section{- Student profile and programme expectation}

The student profile has changed over the years, and it is estimated that today $50 \%$ of the world's population is younger than 30 , the so-called Generation $y$. This generation is the first to have grown up fully with technology, is considered to be very demanding, but also very productive. Generation $y$ is competitive, creative, good with problem-solving and self-assured, but also becomes bored very quickly. Generation y believes in working smart and having a balanced lifestyle. Its members are also well connected via social networks and its wide networking (Booysen, 2013; Kane, 2013).

Students are also increasingly viewing education as an investment and are looking for a pay-off from their studies. Students and their parents are therefore searching for university programmes that will prepare them for the work environment and increase their employability and market worth (Abeysekera, 2006). The South African Graduate Recruiters Association (hereafter SAGRA), which does market research among graduates and employers, found in its candidate survey for 2012 that students base their choice of university largely on the reputation of the institution (64\%) and reputation of the programme they want to study (60\%), and that aspects such as language (12\%), entrance requirements (16\%) and cost of the degree are lesser considerations (SAGRA, 2012a). The 2012 SAGRA survey was the sixth undertaken, and the above findings are in line with those of previous years. 


\section{- Employer expectation}

Employers are increasingly placing emphasis on knowledge professionals, who are professionals who in an ever-changing global business environment display a range of generic capabilities as well as technical skills. Accordingly, HEls programmes cannot any longer be driven entirely by content and theory (De Lange, Jackling \& Glut, 2006). This is confirmed by the SAGRA employers survey of 2012, which indicates that employers place a high emphasis on skills, of which aspects such as willingness to learn (92\%), team working (88\%), problem-solving (86\%) and proactivity $(81 \%)$ are the highest, with the least emphasis being placed on skills such as foreign language (7\%), leadership (40\%), computer literacy (42\%), networking (43\%) and business acumen (48\%) (SAGRA, 2012b). The expectations of the accounting profession, discussed below, further substantiate this.

\section{- Developments in the accounting profession}

Accounting education has long been under intense scrutiny and has received severe criticism for not providing the type of graduates that the accounting profession needs. Various accounting bodies and regulatory agencies have over the years expressed concern that accounting education has over-emphasised the technical abilities of graduates to the detriment of other capabilities. Hence, technical skills and rational approaches to learning have been emphasised to the detriment of developing skills which prepare the student for lifelong learning. This, in line with other developments in the education field, resulted in a shift in focus from a technical knowledge to a competence-based approach to accounting education (Adler \& Milne, 1995, 1997; Agyemang \& Unerman, 1998; Albrecht, Clark, Smith, Stocks \& Woodfield, 1994; Australian Learning \& Teaching Council, 2010; SAICA, 2010; Wessels \& Roos, 2009).

In 2003 the International Accounting Education Standards Board (hereafter IAESB) issued an Educational Standard, IES 2, in which it provides guidance on how educational institutions could develop their curricula using a competency-based approach (IAESB, 2003; Wessels \& Roos, 2009). The standard was revised in 2009 and reissued in 2010, focusing on the need for professional knowledge, skills, values, ethics and attitudes, and being able to integrate these elements. The need for instilling a commitment to lifelong learning in candidates is also emphasised (IAESB, 2010).

These developments in accounting education had a direct impact of the initiatives of SAICA, as discussed in section 3.4 .

\section{- HEls challenges and pressures}

HEls are facing many challenges such as funding constraints and research output pressures, which affect their operations and programme offerings. This is further complicated by factors affecting their teaching and learning strategies and models, such as a diverse student body in respect of race, language and culture, with many coming from disadvantaged educational backgrounds.

To address such aspects and challenges, $\mathrm{HEls}$ are responding by constantly evaluating their programme offerings, as well as their teaching and learning philosophy and strategies. The UJ's response is discussed in sections 3.5 and 3.6 below.

\section{- Changing dogma: Knowledge to skills and lifelong learning}

The traditional dogma on which universities were built was that of 'knowledge', but as far back as 1971 Robert Nisbet, a well-known educationist, questioned whether this is "relevant 
knowledge" or "practical knowledge" (Nisbet, 1971). As discussed in section 3.1, this knowledge-based educational system has come under intense scrutiny, and combined with a changing world environment of super complexity, globalisation, technological advances and the emergence of a knowledge-based society, the educational system required a new approach to teaching and learning within the framework of lifelong learning (Barnett, 2000; 2006; D'Andrea \& Gosling, 2005; European Commission, 2007; Jarvis, 1999). This resulted in HEls re-examining their philosophy of teaching and learning, and this culminated in a shift in focus from acquiring knowledge to acquiring skills. This resulted in, inter alia, programme redesign and curricular alignment of programmes (Barnett, 2009; Boughey, 2011; Lin, 2008).

\subsection{SAICA's Competency Framework}

In South Africa SAICA has for many years relied on a knowledge-based syllabus to direct and inform its education and assessment programmes. In line with the global developments in the accountancy profession, and the shortcomings identified in the education of accounting students as discussed in section 3.3 above, in 2010 as part of its accreditation process SAICA developed a Competency Framework that identifies and describes the professional competencies (knowledge, skills and attributes) that South African CAs should be able to demonstrate at their entry point into the profession. This should occur upon the completion of the required academic programme, training programme, professional programme and assessments and should ensure that newly qualified CAs have not only the technical knowledge, but also the professional skills and competencies to be successful in a wide range of work environments (SAICA, 2010).

The Competency Framework provides the basis upon which the education, training and assessment programmes of SAICA are developed and delivered. The application of the Competency Framework to the academic programme is detailed in the document "Competency Framework - Detailed Guidance for Academic Programmes". This document provides detailed information that enables teaching and learning programmes (academic programmes) to be redesigned and that enables the appropriate assessment of core competencies (SAICA, 2010). In 2010, various workshops in the different disciplines were conducted by SAICA to discuss the Competency Framework holistically. The Competency Framework and its requirements are applicable to the 2013 Initial Test of Competence (SAICA, 2010; Marx \& Van der Watt 2013).

\subsection{The University of Johannesburg teaching \& learning philosophy}

$\mathrm{UJ}$ identified teaching and learning as one of its key strategies in its 2008 strategic plan, and in line with this commitment adopted a teaching and learning strategy underpinned by a philosophy of 'learning to be'. This requires of students to understand the principles, attributes, competencies, activities, procedures and values that drive the subject discipline they are studying. This was in response to the university's recognition of the complexity and rapidly changing nature of the social, economic and intellectual environment for which its students are being prepared, and that accordingly it is imperative that the teaching and learning at the institution should transform from a primary concern with the transmission of knowledge (learning about) to a primary concern with the practices of a knowledge domain (learning to be). Together with the strategy, the university's senate also approved a position paper that underpins the principles of teaching and learning to be applied by faculties, departments and academic staff members. The different faculties were each further required to develop a dedicated focus on teaching and learning that would be embedded in the faculty structures and 
processes (Clarence-Fincham \& Naidoo, 2011; UJ, 2008; Amory, Gravett \& Van der Westhuizen, 2008).

\subsection{Department of Accountancy's response to the drivers for change}

The Department of Accountancy at $\mathrm{UJ}$ responded to the changes discussed under section 3.3, the introduction of the SAICA Competency Framework (section 3.4) and the roll-out of a new teaching philosophy at $U \mathrm{UJ}$ (section 3.5 ) in two ways:

- A decision was made at the beginning of 2010 to introduce a new bachelor's degree that would specifically focus on CA postgraduate studies; and

- A new teaching strategy was developed in an attempt to address the teaching and learning of the diverse student population, and increase the student retention and throughput rates.

The new strategy was implemented in 2010.

The introduction of a new degree (Bachelor of Accounting) was preceded by a process through which a committee was established. The members of the committee comprised academic staff within the department as well as curriculum specialists. In developing the curriculum of the new bachelor's degree, the committee considered several aspects, such as the changing higher education landscape in South Africa, the new generation of students, stakeholder expectations regarding students, the SAICA Competency Framework and the UJ teaching and learning strategy.

At the start of the process, and after due consideration of the drivers for change as highlighted in 3.3 above, the committee developed the degree on the basis of the following guiding principles:

- Develop a programme that has a curriculum specifically aligned with its purpose and exitlevel outcomes;

- The degree should be sufficiently demanding, especially in the first year;

- The degree should focus as much on pervasive skills as it does on technical skills;

- Pervasive and other skills should be developed earlier in the degree in order to allow for the mastering of technical content later in the degree;

- Non-core modules best suited for the development of pervasive skills should be included in the first and second year of the degree;

- Business context must be provided early in the degree in order to facilitate an understanding of complex technical concepts;

- There should be a coherent alignment between modules in terms of purpose and learning outcomes (teaching towards the outcomes and assessing against the outcomes); and

- Strong academic leadership and control to be exercised over supportive and non-core modules.

The committee was of the opinion that the development of a curriculum guided by the above principles would enable the department not only to respond to the learning difficulties experienced by the new generation of students, but also to reduce the gap between undergraduate and postgraduate studies as experienced by students. The new Bachelor of Accounting degree was approved internally by UJ during 2010 and externally by the Department 
of Higher Education and Training in 2011. The first group of students registered for the new degree at the beginning of 2012.

Previously, lecturers applied their own teaching and learning approaches and methods in teaching accountancy students. In the light of all the challenges and demands the department faced it developed a new teaching and learning strategy for the accountancy department in collaboration with various stakeholders such as the academic staff, external consultants from SAICA and higher education specialists. The UJ's new teaching and learning policy and strategy formed the basis of the development of a new teaching strategy that is more focused on the current student profile and that engages better with the lecturers and students. One of the most important features of the newly developed teaching and learning strategy is that it is a cyclical process in nature. It was also important to get buy-in, a common understanding and commitment among staff members. Several workshops were conducted during the initial implementation phase and the implementation was carefully monitored by a dedicated staff member and the head of the department. Regular feedback and reflection on an on-going basis from both students and staff contributed to improving the strategy.

The teaching and learning strategy is underpinned by the following principles of good teaching and learning practice (Biggs, 2003; Chalmers \& Fuller, 1996; Chickering \& Gamson, 1987 \& 2000; Habeshaw, Gibbs \& Habeshaw, 1993; Hatfield, 1995):

- It is informed by the UJ teaching and learning strategy and underpinning philosophy;

- Good teaching and learning practice communicates high but realistic expectations and provides appropriate support;

- Teaching and learning should be interactive, collaborative and reflective, and should respect diverse talents and ways of learning and acknowledge student diversity, while emphasising students' ability to become lifelong learners;

- Learning must incorporate a variety of resources, all of which have a specific learning and teaching objective that is based on interconnected knowledge and the creation of a meaningful and relevant context for learning;

- Teaching should primarily be based on the principles of good teaching, the learning of reflective practices, and constructive, prompt feedback;

- The teaching strategy includes and accommodates the development of pervasive and other soft skills;

- The strategy aims to guide students to become leaders in world of business;

- The lecturer should mainly facilitate and manage the teaching and learning process;

- Students are encouraged to become self-directed learners who take responsibility for their own learning; and

- The strategy accommodates student self-assessment and reflection practices upon their learning to ensure that they are well prepared for formative assessment opportunities.

The new teaching and learning strategy can best be described as a blended approach to teaching and learning, incorporating different learning resources. The meaning and role of each of the resources available to students as part of the learning process can be explained as follows: 


\section{(a) Pre-reading}

Students are given relevant reading material in preparation for the next class. The objective is to provide students with the context of the topic to be covered during the next class in order for them to be familiar with the new topic. Lecturers should encourage students to do the prereading through some form of follow-up. Students should feel that they are being deprived of something valuable if they do not utilise this resource.

\section{(b) Objective tests}

The objective of this resource is to enable students to self-assess their understanding of the topics covered during the previous lecture. The whole exercise should not take longer than 15 minutes and students should get immediate, constructive feedback. Discussions and questions from students are limited and students are reminded that they should identify a problem regarding a lack of knowledge and then act by going back to the work covered.

\section{(c) Class experience}

The contact session (class) remains the most important resource in the teaching and learning experience, but it must be emphasised to students that it is only one of many resources. Based on the principle that lecturers are mainly facilitators of learning, sufficient time should be spent during the class on explaining to students how the different resources should be utilised to master the specific topic under discussion.

Teaching in class should focus on principles, but should also demonstrate to students some of the application by means of basic examples. The lecturers should also indicate to students which questions in the question bank can best serve as "building-block" knowledge and which of the questions are best suited for self-assessment. Guidance should also be given to students on how much time they should spend on each of the learning resources.

\section{(d) Study or learner guide}

A study guide is provided to students in class for each of the topics. The study guides explain the role and expectations of each of the learning resources.

\section{(e) Self-study}

The importance of self-study should be emphasised, and guidance should be given on what it should entail in order to assist students to become self-directed learners who take responsibility for their own learning.

\section{(f) Consultation}

Students are encouraged to consult with lecturers, but it should also be emphasised that students should first attempt to resolve problem areas themselves or through collaboration with their peers.

\section{(g) Peer cooperation}

Students are encouraged to work within groups to enable collaborative learning and to learn from each other. 


\section{(h) Assignments}

The completion and submission of assignments is an important part of formative assessment. The assignments should be on a high, but realistic, standard and students should be in a position to self-assess what they have learnt. The number of assignments students should do should be agreed upon with their lecturers in a year-group in order not to overburden students during certain times of the year. Constructive feedback on assignments should take place formally and timeously.

\section{(i) Tutorials}

Small-group tutorials should primarily be used to develop pervasive and other soft skills. They should also be an integral part of the teaching and learning process. Lecturers can either use tutorials for the hand-in and discussion of assignments, or previously unseen questions can be discussed in order to explain the application of the principles.

The use of small-group tutorials is currently de-emphasised as part of the teaching and learning approach for honours students because of a lack of tutorial venues. Lecturers are however encouraged to attempt to simulate the experience as part of the class experience.

\section{(j) Self-assessment}

The concept of self-assessment should be explained clearly to students, and they should be encouraged to use the opportunity to self-assess to determine if they understand the learning content.

\section{(k) Formal assessment}

Formal assessments should not be a surprise to students in terms of standard etc. within the context of the focus on self-assessment. Attendance of tutorials and submission of assignments are included in the requirements for examination entry.

The teaching and learning strategy can be diagrammatically set out as follows in FIGURE 1 :

\section{METHODOLOGY}

Numerous in-depth discussions of the philosophy of teaching and learning and the requirements for a teaching and learning strategy that will conform to both the SAICA Competency Framework requirements and the UJ'S teaching philosophy were held with executives of the education unit and other interested parties at SAICA and UJ's Centre for Professional Academic Staff Development. Their views on how to assess the success thereof were considered and incorporated in the design of the questionnaire and the interpretation of the results with the aim of understanding and assessing the students' understanding and experience of the teaching and learning approach. 


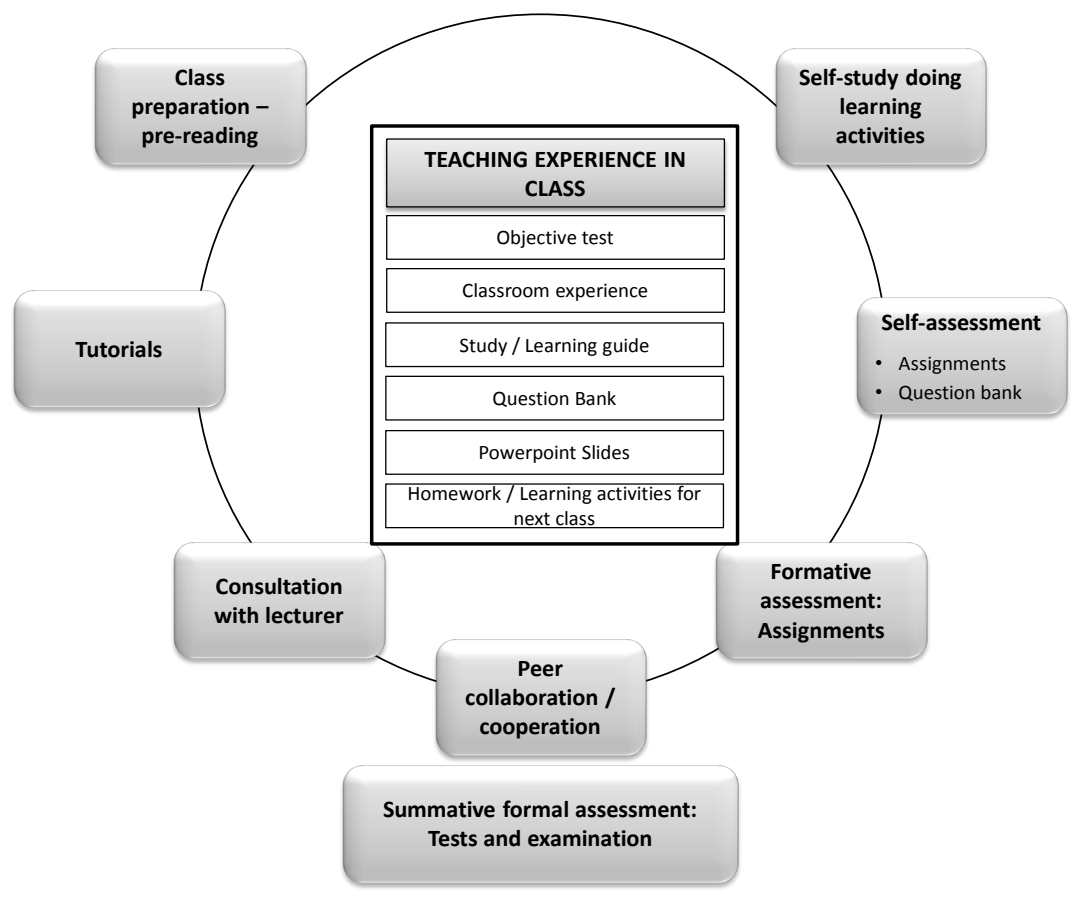

FIGURE 1: Diagrammatic presentation of the new teaching and learning strategy

Source: Authors'interpretation

Lecturers are encouraged to ensure that students understand the above strategy, as it is a factor that is critical to the success of the project.

\subsection{Population and response rate}

The population for the empirical study was the BCom Honours students (with Specialisation in Chartered Accountancy) at UJ. Questionnaires were distributed to the students in their final class of the year in October 2011 and October 2012 respectively, thus allowing them to reflect on their learning experience for the full year. The questionnaires received back represented a response rate of $97.7 \%$ (426 received back from a class of 436) for 2011 and a response rate of 97.9\% (466 received back from a class of 476 ) for 2012.

\subsection{Questionnaire design and control}

The questionnaires were developed by taking into account the literature review and the department's teaching and learning strategy. A mixed-method approach, including elements of both quantitative and qualitative research, was followed. The questionnaires also included open-ended sections where respondents could provide their views and concerns, and make comments, thus allowing for descriptive responses to enrich and expand the research results. Such an approach allows for both quantitative (positivist) and qualitative (interpretive) research evidence, and is well supported in the literature (Broadbent, \& Unerman, 2011; Creswell \& Plano Clark, 2007; Golafshani, 2003; Henning, Van Rensburg \& Smit, 2004; Morse \& Niehaus, 2009). The closed-ended questions followed a five-point Likert category scale with the options 
of "strongly disagree" to "neutral" to "strongly agree". Reliability on the close-ended questions on the five-point Likert scale is 0.917 using the Cronbach's alpha reliability test. In the questions regarding the students' understanding of the approach three options were given and the students had to choose one. The questionnaire was piloted with a selected group of experienced academics, as well as academic trainees, who provided valuable input into the questionnaire design and content, contributing to its relevance.

Honours students are considered conscientious and mature members of the student community and it was therefore accepted that they would exercise the necessary diligence and due care in the completion of the questionnaires. This was also emphasised by the researchers when the empirical study was conducted. Accordingly, it was not considered necessary to test for prejudice or contradictions. The data was processed and analysed by the researchers and independently checked and reviewed for accuracy.

\section{RESEARCH FINDINGS AND INTERPRETATION}

\subsection{Student profile}

\subsubsection{Objective of the questions}

The objective of these questions was to understand the student population and profile, and the factors that may impact on the programme offering and success rate.

\subsubsection{Findings and deductions}

The findings indicate that most of the students are 30 years or younger $(99.3 \%$ in 2011 and $99.6 \%$ in 2012), which means that they fall within the Generation $y$ category with its specific characteristics (competitive, creative, focused on problem-solving, self-assured, IT-literate and very active on social networks) as discussed in section 3.3 and accordingly the teaching and learning approach should cater for this. The majority of the students are female $(55.9 \%$ in 2011 and $54.2 \%$ in 2012) and as far as population grouping are concerned, mainly African ( $48.1 \%$ in 2011 and $47.0 \%$ in 2012) and White (32.6\% in 2011 and $36.7 \%$ in 2012) with Indian students ( $9.4 \%$ in 2012 and $7.1 \%$ in 2012) and Coloured students ( $4.7 \%$ in 2011 and $3.2 \%$ in 2012) making up the rest. These findings indicate that the student body is representative of the demographics of the country and in line with the government's objective for higher education as discussed in section 3.1 .

As far as language is concerned, it is important to note that the majority of students are studying in a language that is not their primary home language: in 2012 a total of $48.6 \%$ of students had a primary home language other than English or Afrikaans (the BCom Honours classes are offered in English or Afrikaans). Thus it is obvious that language proficiency could be one of the challenges that could affect student success rates, as discussed in section 3.3.

The fact that almost a quarter of the class did not do their undergraduate studies at $U \mathrm{~J} \mathrm{could}$ also offer a challenge, as these students might not be familiar with the teaching and learning strategy followed at postgraduate level at the university.

Students generally also have access to computer facilities (computers, printers and internet) and a quiet place to study, with the majority in 2012 studying at home (59.4), UJ library (16.5\%) 
or in a $\mathrm{UJ}$ residence. Of concern is that $6.7 \%$ indicated $(6.6 \%$ in 2011$)$ that they do not have a quiet place to study.

Students commented in the open-ended section that although they have sufficient access to computer facilities they do not really need these for study purposes. The library study facility seems to be problematic, however, with many students commenting that it has insufficient capacity during peak times, and does not cater for the specific needs of the BCom Honours students studying long hours. The need for a "CTA postgraduate study centre" was raised by many respondents.

\subsection{BCom degree as preparation for BCom honours degree}

\subsubsection{Objective of the questions}

The objective of these questions was to understand whether the BCom degree prepared the students for their BCom honours study.

\subsubsection{Findings and deductions}

Most students (75.7\% in 2011 and $74.3 \%$ in 2012) are of the opinion that the B Com degree prepared them sufficiently for the honours degree. A matter of concern was that, on average, $25 \%$ of the students felt that they were not sufficiently prepared for the postgraduate degree. The students' responses in 2011 and 2012 on the aspects of the B Com degree preparing them sufficiently for the honours degree varied substantially.

From the results it appears that the students felt that the volume of study material $(76.3 \%$ in 2011 and $51.4 \%$ in 2012); the complexity of learning material ( $73.5 \%$ in 2011 and $53.3 \%$ in 2012 ); the teaching and learning approach of the lecturers (65.7\% in 2011 and $59.7 \%$ in 2012$)$; the tests/examinations ( $53.3 \%$ in 2011 and $54.2 \%$ in 2012) and attending all classes (42.7\% in 2011 and $63.2 \%$ in 2012) contributed the most in preparing them for the honours degree. The 2012 student group benefited more in consulting their lecturers (6.1\% in 2011 and $37.1 \%$ in 2012); doing all assignments (17.1\% in 2011 and $41.4 \%$ in 2012) and feedback received from lecturers ( $9.6 \%$ in 2011 and $35.9 \%$ in 2012). The lower percentages for 2012 could possibly be explained by the fact that the lecturers themselves understood the teaching and learning strategy better in 2012 , as it was the second year that they had applied it, and accordingly made adjustments to the study material and their teaching and learning approach as learnt from experience in 2011.

The following aspects had a meaningful impact on the differences the students experienced between the undergraduate B Com and the B Com Honours degree (students could indicate more than one aspect):

TABLE 1: Different aspects that impact on students

\begin{tabular}{lcc}
\multicolumn{1}{c}{ Aspects } & 2011 & 2012 \\
& $\%$ & $\%$ \\
\hline The volume of study material & 99.1 & 82.5 \\
The complexity of learning material & 97.7 & 63.3 \\
The teaching and learning approach of the lecturers & 95.3 & 26.6
\end{tabular}




\begin{tabular}{lcc}
\multicolumn{1}{c}{ Aspects } & 2011 & 2012 \\
& $\%$ & $\%$ \\
\hline The difficulty of tests & 87.6 & 72.4 \\
The difficulty of examinations & 71.8 & 72.1 \\
The difficulty of assignments & 60.1 & 28.9 \\
Integration of all four subjects in examinations & 48.8 & 56.8 \\
Pressure in terms of the volume of work & 38.3 & 79.3 \\
Pressure in terms of the difficulty of work & 25.8 & 42.5 \\
Pressure in terms of the complexity of work & 16.9 & 50.5 \\
The expected high standard of work & 8.7 & 48.6 \\
Studying independently & 2.1 & 12.1 \\
\hline
\end{tabular}

Source: Authors' analysis

The UJ group of 2011 was exposed to the new teaching and learning strategy from their second year, whereas the UJ group of 2012 followed the teaching and learning strategy for the entire three years of the undergraduate degree. This, coupled with the full exposure to the teaching and learning strategy, might explain why certain aspects impacted differently on the 2011 and 2012 groups. The biggest differences between certain aspects for both groups are clearly presented in the table.

\subsection{Departmental communication of the teaching and learning strategy}

\subsubsection{Objective of the questions}

The objective of these questions was to assess whether the teaching and learning approach was sufficiently communicated and explained to the students.

\subsubsection{Findings and deductions}

The majority (93.7\% in 2011 and $91.3 \%$ in 2012) are aware of the teaching and learning approach of the department, and the majority of the $\mathrm{BCom}$ Hons students agree that the lecturers explained the teaching and learning approach to them ( $93.3 \%$ in 2011 and $95.0 \%$ in 2012).

\subsection{Students' opinion on their understanding of the teaching and learning strategy}

\subsubsection{Objective of the question}

The objective of these questions was to determine if the students felt that they understood the teaching and learning strategy as a whole. 


\subsubsection{Findings and deductions}

It is clear from the data that $91.0 \%$ of the students in 2011 and $84.3 \%$ of those in 2012 were of the opinion that they understood the departmental teaching and learning approach.

\subsection{Students' real understanding of the teaching and learning strategy}

\subsubsection{Objective of the questions}

The objective of these questions was to determine whether the students really understood the different components of the teaching and learning strategy.

\subsubsection{Findings and deductions}

The students had to select one of three options as to what the purpose of the different components of the departmental teaching and learning strategy is.

The findings reveal that:

- $78.9 \%$ of the students in 2011 and $80.3 \%$ of those in 2012 understood that the purpose of class preparation was to be familiar with the work to be lectured.

- $91.8 \%$ in 2011 and $87.0 \%$ in 2012 understood that the purpose of the objective test was to assess their understanding of the principles of the work.

- $86.1 \%$ in 2011 and $91.3 \%$ in 2012 understood that the purpose of classroom teaching/ lecturing was for the lecturer to guide/facilitate their learning on the topic.

- $83.3 \%$ in 2011 and $84.0 \%$ in 2012 understood that the purpose of using PowerPoint slides by the lecturer was to provide key aspects on the topic during lectures.

- $89.6 \%$ in 2011 and $88.7 \%$ understood that the purpose of the study guide was to know what they were expected to learn.

- $90.5 \%$ in 2011 and $93.7 \%$ in 2012 understood that the purpose of the question bank in their study guide was to do the questions in their own time.

- $86.3 \%$ in 2011 and $88.1 \%$ understood that the purpose of being given homework/ assignments to complete before the next class was to master the application of the principles of the work.

- $96.5 \%$ in 2011 and $94.8 \%$ in 2012 understood that the purpose of self-study was to make sure that they understood the work and could apply the knowledge.

- $94.8 \%$ in 2011 and $93.9 \%$ in 2012 understood that the purpose of consulting with their peers (fellow students) was to identify problems and seek solutions collaboratively.

- $93.6 \%$ in 2011 and $90.5 \%$ in 2012 understood that the purpose of self-assessment was to determine how well they knew the topic and if they could apply their knowledge.

- $88.6 \%$ in 2011 and $86.3 \%$ in 2012 understood that the purpose of doing assignments was to determine if they could apply the principles to real-world problems.

- $97.6 \%$ in 2011 and $98.7 \%$ in 2012 understood that the purpose of consulting their lecturers was to assist them when they could not solve a problem themselves. 
- $57.4 \%$ in 2011 and $67.9 \%$ in 2012 understood that the purpose of group classes was to focus on examples to guide their learning.

Although the findings indicate that a percentage of the students really understand the different aspects of the teaching and learning approach, the department should reflect on ways to ensure that all the students have a better understanding of the approach. Important aspects of the teaching and learning approach need to be more clearly communicated to the students, such as class preparation, the use of slides, doing assignments and homework, and use of the study guide. The lecturers should strive towards a $100 \%$ understanding of the teaching and learning approach to more meaningful integrated learning and throughput.

Students' comments in the open-ended section indicated an understanding of the different aspects of the teaching and learning strategy, and that it helped them in approaching their studies and its different components. The majority of the students, however, felt that the group classes were not very helpful, and that the groups were too big. This can possibly be explained by the $U$ J constraint on lecturing facilities, which is not conducive to optimal group-class engagement.

\subsection{Students' experience of the teaching and learning strategy}

\subsubsection{Objective of the questions}

The objective of these questions was to determine the extent to which each of the aspects describing some personal factors/options characterised, or described, the students' own experience of the teaching and learning approach during their postgraduate study.

\section{TABLE 2: Students' experiences of the teaching and learning approach}

\begin{tabular}{|c|c|c|c|c|c|c|}
\hline \multirow{2}{*}{$\begin{array}{c}\text { Statements related to the different } \\
\text { components of the teaching and learning } \\
\text { approach }\end{array}$} & \multicolumn{2}{|c|}{ Disagree } & \multicolumn{2}{|c|}{ Neutral } & \multicolumn{2}{|c|}{ Agree } \\
\hline & 2011 & 2012 & 2011 & 2012 & 2011 & 2012 \\
\hline I prepared for each class & 15.8 & 20.2 & 45.0 & 41.8 & 39.2 & 38.0 \\
\hline $\begin{array}{l}\text { I did the recommended pre-reading before I } \\
\text { attended the next class }\end{array}$ & 15.8 & 14.8 & 24.2 & 33.6 & 60.0 & 51.6 \\
\hline I found it useful to prepare for each class & 7.4 & 9.9 & 20.2 & 26.9 & 72.4 & 63.2 \\
\hline I attended all classes & 2.1 & 1.1 & 2.8 & 4.8 & 95.1 & 94.1 \\
\hline $\begin{array}{l}\text { I studied for the recommended } 48 \text { hours per } \\
\text { week }\end{array}$ & 7.8 & 8.4 & 21.6 & 24.9 & 70.6 & 66.7 \\
\hline $\begin{array}{l}\text { I knew that I had to apply the principles } \\
\text { learnt from the previous topic lectured for } \\
\text { the next objective class tests }\end{array}$ & 4.0 & 3.8 & 11.3 & 19.8 & 84.7 & 76.4 \\
\hline $\begin{array}{l}\text { I used the PowerPoint slides as the key } \\
\text { aspects of the topic to study }\end{array}$ & 20.7 & 17.6 & 22.4 & 23.3 & 56.9 & 59.1 \\
\hline $\begin{array}{l}\text { I used the provided study/learning guides } \\
\text { regularly }\end{array}$ & 2.1 & 2.0 & 5.4 & 7.1 & 92.5 & 90.9 \\
\hline
\end{tabular}




\begin{tabular}{|c|c|c|c|c|c|c|}
\hline \multirow{2}{*}{$\begin{array}{c}\text { Statements related to the different } \\
\text { components of the teaching and learning } \\
\text { approach }\end{array}$} & \multicolumn{2}{|c|}{ Disagree } & \multicolumn{2}{|c|}{ Neutral } & \multicolumn{2}{|c|}{ Agree } \\
\hline & 2011 & 2012 & 2011 & 2012 & 2011 & 2012 \\
\hline I participated in class discussions & 33.3 & 34.7 & 36.9 & 35.2 & 29.8 & 30.1 \\
\hline $\begin{array}{l}\text { I knew what was expected of me to learn as } \\
\text { indicated in the learning guide }\end{array}$ & 1.6 & 3.3 & 11.1 & 14.4 & 87.3 & 82.3 \\
\hline $\begin{array}{l}\text { The study/learning guides were well } \\
\text { structured }\end{array}$ & 2.1 & 2.8 & 9.0 & 9.7 & 88.9 & 87.5 \\
\hline $\begin{array}{l}\text { The learning outcomes in my learning guide } \\
\text { directed my learning }\end{array}$ & 5.2 & 7.2 & 19.0 & 19.2 & 75.8 & 73.6 \\
\hline $\begin{array}{l}\text { I did all the homework/learning activities } \\
\text { before the next class }\end{array}$ & 3.8 & 6.9 & 23.3 & 26.3 & 72.9 & 66.8 \\
\hline I took responsibility for my own learning & 2.4 & 1.3 & 4.3 & 5.4 & 93.3 & 93.3 \\
\hline I collaborated with my peers on the work & 12.5 & 8.5 & 20.1 & 21.5 & 67.4 & 70.0 \\
\hline $\begin{array}{l}\text { I benefited from cooperating with my peers } \\
\text { on the work }\end{array}$ & 14.0 & 10.3 & 19.0 & 19.7 & 67.0 & 70.0 \\
\hline $\begin{array}{l}\text { Learning with my peers promoted my own } \\
\text { knowledge construction }\end{array}$ & 14.5 & 10.5 & 19.1 & 21.7 & 66.4 & 67.8 \\
\hline I had a fixed group of peers & 27.0 & 20.0 & 19.3 & 20.2 & 53.7 & 59.8 \\
\hline My peer group met at least once a week & 51.5 & 49.3 & 21.5 & 21.9 & 27 & 28.8 \\
\hline I did the self-assessment & 2.9 & 3.5 & 14.2 & 17.8 & 82.9 & 78.7 \\
\hline I did the assignment & 2.6 & 1.6 & 7.2 & 7.4 & 90.2 & 91.0 \\
\hline $\begin{array}{l}\text { I experienced self-assessment as a very } \\
\text { important way of preparing for the tests }\end{array}$ & 3.1 & 5.3 & 13.6 & 18.6 & 83.3 & 76.1 \\
\hline $\begin{array}{l}\text { I experienced self-assessment as a very } \\
\text { important way of preparing for the } \\
\text { examination }\end{array}$ & 3.3 & 5.9 & 12.0 & 16.7 & 84.7 & 77.4 \\
\hline $\begin{array}{l}\text { I experienced assignments as a very } \\
\text { important way of preparing for the tests }\end{array}$ & 7.5 & 8.3 & 18.8 & 18.2 & 73.7 & 73.5 \\
\hline $\begin{array}{l}\text { I experienced assignments as a very } \\
\text { important way of preparing for the } \\
\text { examination }\end{array}$ & 8.3 & 8.6 & 17.4 & 18.5 & 74.3 & 72.9 \\
\hline $\begin{array}{l}\text { I consulted my lecturers/academic article } \\
\text { clerks if I could not solve a problem }\end{array}$ & 17.3 & 14.7 & 24.3 & 18.3 & 58.4 & 67.0 \\
\hline I benefited from the group classes offered & 12.7 & 13.9 & 19.0 & 23.1 & 68.3 & 63 \\
\hline $\begin{array}{l}\text { I received prompt feedback on my } \\
\text { assignments }\end{array}$ & 9.7 & 15.4 & 25 & 31.9 & 65.3 & 52.7 \\
\hline $\begin{array}{l}\text { I received constructive feedback on my } \\
\text { assignments }\end{array}$ & 12.3 & 14.2 & 22 & 31.4 & 65.7 & 54.4 \\
\hline
\end{tabular}




\begin{tabular}{|c|c|c|c|c|c|c|}
\hline \multirow{2}{*}{$\begin{array}{c}\text { Statements related to the different } \\
\text { components of the teaching and learning } \\
\text { approach }\end{array}$} & \multicolumn{2}{|c|}{ Disagree } & \multicolumn{2}{|c|}{ Neutral } & \multicolumn{2}{|c|}{ Agree } \\
\hline & 2011 & 2012 & 2011 & 2012 & 2011 & 2012 \\
\hline $\begin{array}{l}\text { I received constructive feedback on my } \\
\text { tests }\end{array}$ & 4.1 & 4.5 & 18.6 & 15.7 & 77.3 & 79.8 \\
\hline $\begin{array}{l}\text { As a result of my experience so far I have } \\
\text { improved my ability to learn independently }\end{array}$ & 1.4 & 1.1 & 5.0 & 6.1 & 93.6 & 92.8 \\
\hline $\begin{array}{l}\text { My lecturers have the necessary subject } \\
\text { knowledge to adequately teach the subject }\end{array}$ & 1.4 & 0.7 & 2.6 & 2.9 & 96.0 & 96.4 \\
\hline $\begin{array}{l}\text { My lecturers have the necessary skills to } \\
\text { adequately teach the subject }\end{array}$ & 2.1 & 1.6 & 3.4 & 3.4 & 94.5 & 95.0 \\
\hline
\end{tabular}

Source: Authors' analysis

The data contained in TABLE 2 should be interpreted in relation to the students' understanding of the purpose of the different components of the teaching and learning approach. From the data it is clear that students' understanding of the approach and how they act on and experienced the different components thereof differs. Lecturers should probably repeatedly communicate the different resources and their purposes to students more effectively. The data reveals a reasonably high level of understanding of the purposes of using the different learning resources, as well as a reasonably good level of understanding as to how to apply the different resources.

\subsection{Students' experience of the carbon-copy mid-year examination method}

The mid-year examinations are written on carbon copy paper, and the students hand in the top copy and keep the carbon copy. This they then mark in their own time, write a report on what they did right and what they did wrong, as well as how they think they can improve, and then submit the report and their marks to the department. The students' original copies are then formally assessed and compared to the student mark submitted, and only if the mark is within $10 \%$ of the official mark will the script be released to the students.

\subsubsection{Objective of the questions}

The objective of this question is to access how students experienced the carbon copy method used as a learning tool during the mid-year examination sessions.

\subsubsection{Findings and deductions}

The students clearly indicated that they experienced the carbon copy mid-year examinations marking exercise as very positive: $93.5 \%$ in 2011 and $89.7 \%$ in 2012 agreed that it is a useful and meaningful learning experience.

Furthermore, the findings revealed that:

- $91.1 \%$ of the students in 2011 and $69.3 \%$ of those in 2012 stated that it helped them to improve their examination technique. 
- $81.7 \%$ in 2011 and $69.0 \%$ in 2012 realised that they lack knowledge in certain areas of the work.

- $63.6 \%$ in 2011 and $42.9 \%$ realised that they could not apply the principles.

- $36.4 \%$ in 2011 and $33.9 \%$ stated that it prepared them for the final examination.

- $19.0 \%$ in 2011 and $38.6 \%$ realised that they need to do more examples.

- $10.6 \%$ in 2011 and $47.6 \%$ in 2012 realised that they should work harder.

Students commented in the open-ended section that the use of the carbon copy was very useful and indicated aspects that they need to improve upon. This included aspects such as the need to structure answers and put forward logical arguments, and to write neatly and focus on certain aspects in order to score marks. Other aspects listed that benefited them included the identifying of knowledge gaps, the fact that they did not work hard enough and accordingly lacked knowledge, as well identifying problems with, and improving, time and stress management.

\section{Summative findings}

The above findings indicate that the students experienced the new teaching and learning strategy applied very positively, and that it also impacted on their approach to their studies. An aspect of concern, however, is that the group classes were not experienced very positively by the students. The lack of tutorial facilities is a limiting factor in this regard, and is an aspect that should receive attention by the university authorities.

Overall it can be deduced that the management of the Department of Accountancy has, based on the dimension of the students' perspective, succeeded in changing its teaching and learning approach; however, such a newly implemented strategy needs to be reflected upon and evaluated on an on-going basis. Room for improvement still exists, and lecturers should constantly focus on clearly communicating the new teaching and learning strategy and the purpose of each resource more effectively to students, and find ways and means of further encouraging students to follow this cyclical teaching and learning approach.

The success of the new teaching and learning approach is also evident in the fact that the throughput rate for the student group increased from $57 \%$ (243 students) in 2010 before the new teaching and learning strategy was implemented to 63\% (273 students) in 2011 and $62 \%$ (290 students) in 2012.

\section{CONCLUSION AND AREAS FOR FUTURE RESEACH}

From this research it is evident that there are many factors that impact on the learning and performance of today's accounting students and that it is essential that the teaching and learning that take place take cognisance of this, as well as of the changing needs of students and stakeholders alike. This study found that a well-designed and -implemented teaching and learning strategy can play a meaningful role in enabling and improving student learning, with a consequent improvement in marks and higher throughput rates.

Given the results of this study, it is recommended that accountancy departments give careful consideration to their current teaching and learning approaches and practices, and to evaluate 
if they meet the changing educational landscape and stakeholder needs. It would also be of interest to do a similar study on teaching and learning at non-SAICA-accredited HEls in South Africa. It is also recommended that this study be extended to other CA programmes, as well as distance learning programmes.

\section{LIST OF REFERENCES}

Abeysekera, I. (2006). Issues Relating to Designing a Work-integrated Learning Program in an Undergraduate Accounting Degree Program and its Implications for the Curriculum. Asia Pacific Journal of Cooperative Education, 7(1), pp. 7-15.

Adler, R.W. \& Milne, M. (1995). Increasing learner-control and reflection: towards learning-to-learn in an undergraduate management accounting course. Accounting Education, 4(2), pp. 105-119.

Adler, R.W. \& Milne, M. (1997). Improving the quality of accounting students' learning through action-orientated learning tasks. Accounting Education, 6(3), pp. 191-215.

Agyemang, G \& Unerman, J. (1998). Personal skill development and first year undergraduate accounting education: a teaching note. Accounting Education, 7(1), pp. 87-92.

Albrecht, W.S., Clark, D. C., Smith, J.M., Stocks, K.D. \& Woodfield, L.W. (1994). An Accounting Curriculum for the Next Century. Issues in Accounting Education, 9(2), pp. 401-426.

Amory, A, Gravett, S.J. \& Van der Westhuizen, D. (2008). Teaching and learning at the University of Johannesburg: a position paper. Document SEN 252/2008(5).

Australian Learning \& Teaching Council. (2010). Learning and Teaching Academic Standards Project. Strawberry Hills, NSW.

Barac, K., Marx, B. \& Moloi, T. (2011). Corporate Governance Practices at South African Higher Education Institutions: An Annual Report Disclosure Analysis. Journal of Economic and Financial Sciences, 4(2), pp. 317-332.

Barac, K., \& Marx, B. (2012). Corporate Governance effectiveness and value added at South African Higher Education Institutions: A Registrar's View. Journal of Economic and Financia/ Sciences, 5(2), pp. 351-372.

Barnett, R. (2000). Supercomplexity and the curriculum. Studies in Higher Education, 25(3), pp. 255265.

Barnett, R. (2006). Graduate Attributes in the Age of Uncertainty. In P. Hager \& S, Holland (eds), Graduate Attributes, Learning and Employability, pp. 49-65. Netherlands: Springer.

Barnett, R. (2009). Knowing and becoming in the higher education curriculum. Studies in Higher Education, 34(4), pp. 429-440.

Biggs, J. (2003). Teaching for Quality Learning at University, $2^{\text {nd }}$ edition. SRHE \& Open University Press.

Booysen, V. (30 Januarie 2013). Generasie Y verg nuwe benadering. Sake 24, page 22.

Boughey, C. (2011). Institutional Difference: A Neglected Consideration in the Scholarship of Teaching and Learning? International Journal for the Scholarship of Teaching and Learning, 5(1).

[Online] Available: http://www.georgiasouthern.edu/iisotl. (Accessed 14 March 2013)

Broadbent, J. \& Unerman, J. (2011). Developing the relevance of the accounting academy. Meditari Accountancy Research, 19(1/2), pp. 7-21. 
Chalmers, D. \& Fuller, R. (1996). Teaching for Learning at University: Theory and practice. London: Kogan Page.

Chickering, A. W. \& Gamson, Z. F. (1987). Seven Principles of Good Practice in Undergraduate Education. [Online] Available:

https://scholar.vt.edu/access/content/user/adevans/Public/DVDPortfolio/Samples/samples/traini ng/track_d/Introduction/Best\%20Practices/Article\%20\%207\%20Principles\%20of\%20Good\%20Practice\%20in\%20Undergrad\%20Ed.pdf. (Accessed 17 June 2013).

Clarence-Fincham, J. \& Naidoo, K. (2011). "Learning to be": An exploration of the implementation of curriculum reform in two disciplines at the University of Johannesburg, South Africa. SOLSTICE \& CLTR Conference. Edge Hill University, Lancashire, London. 8 June 2011.

Council for Higher Education, (CHE). (2007). A Case for Improving Teaching and Learning in South African Higher Education. Higher Education Monitor. [Online] Available: http://www.che.ac.za/documents/d000155/. (Accessed 31 January 2013).

Council for Higher Education, (CHE). (2009a). Report of the Council on Higher Education's Consultative Conference, 2009. [Online] Available : http://www.che.org.za/documents/d000203/. (Accessed 15 October 2010).

Council for Higher Education, (CHE). (2009b). The Response of the Council on Higher Education to the report of the Ministerial Committee on Transformation and Social Cohesion and the Elimination of Discrimination in Public Higher Education Institutions. [Online] Available: http://www.che.org.za/documents/d000202/. (Accessed 15 October 2010).

Council for Higher Education. (CHE) (2010). Community Engagement in South Africa Higher Education. [Online] Available: http://www.che.org.za/documents/d00204/. (Accessed 10 0ctober 2010).

Creswell, J.W. \& Plano Clark, V.L. (2007). Designing and conducting mixed methods research. California, USA: Sage Publications, Inc.

De Lange, P, Jackling, N. \& Gut, A.M. (2006). Accounting graduates' perception of skill emphasis in undergraduate courses: an investigation from two Victorian universities. Accounting and Finance, 46(3), pp. 356-386.

De la Harpe, B. \& Radloff, A. (2000). Informed Teachers and Learners: the importance of assessing the characteristics needed for lifelong learning. Studies in Continuing Education, 22(2), pp. 169-182.

D’Andrea, V. \& Gosling, D. (2005). Improving Teaching and Learning in Higher Education. Open University Press. [Online] Available: http://www.abebooks.com/9780335210688/ImprovingTeaching-Learning-Higher-Ed. (Accessed 11 December 2012).

European Commission. (2007). What is lifelong learning? The view from the European Commission Society of Association Executives. [Online] Available: http://www.esae.org/articles/2007_08_005.pdf. (Accessed 31 January 2013).

Golafshani, N. (2003). Understanding reliability and validity in qualitative research. The Qualitative Report, 8(4), pp. 597-607.

Habeshaw, S., Gibbs, G. \& Habeshaw, T. (1993). 53 Interesting Ways to Assess Your Students, $3^{d}$ edition. Bristol: Technical and Educational Services.

Hatfield, S.દ. (દd.) (1995). The Seven Principles in Action: Improving undergraduate education. Bolton: Anker. 
Hall, M., Symes, A. \& Luescher, T.M. (2002). Governance in South African Higher Education: Research Report Prepared For The Council Of Higher Education. CHE: South Africa.

Henning, દ., Van Rensburg, W. \& Smit, B. (2004). Finding your way in qualitative research, $2^{\text {nd }}$ edition. Pretoria: Van Schaik Publishers.

Institute of Directors. (IOD). (2009). King Report on Corporate Governance for South Africa. Institute of Directors in Southern Africa, Johannesburg, South Africa.

International Accounting Education Standards Board. (IAESB). (2003). International Education Standard 2: Towards competent professional accountants. IFAC. New York.

International Accounting Education Standards Board. (IAESB). (2010). International Education Standard 2: Content of Professional Accounting Education Programs. IFAC. New York.

Jarvis, P. (2011). Global Trends in Lifelong Learning and the Response of the Universities. Comparative Education, 35(2):249-257.

Kane, S. (2013). Generation y. [Online] Available:

http://legalcareers.about.com/od/practicetips/a/Generationy.htm. (Accessed 3 February 2013).

Kulati, T. (2000). Governance, leadership and institutional change in South African Higher Education: grappling with instability. Tertiary Education and Management, 6, pp. 177-192.

Küpper, H. (2003). Management mechanisms and financing of higher education in Germany. Higher Education Management and Policy, 15(1), pp. 71-89.

Lin, H. (2011). Blended Online Components into Traditional Instruction in Pre-Service Teacher Education: The Good, the Bad, and the Ugly. International Journal for the Scholarship of Teaching and Learning, 2(1). [Online] Available: http://www.georgiasouthern.edu/iisotl. (Accessed 16 February 2013)

Mayhew, M.J., Wolniak, G.C. \& Parcella, T. (2008). How Educational Practices Affect the Development of Life-long Learning Orientations in Traditionally-aged Undergraduate Students. Research in Higher Education, 49, pp. 337-356.

Marx, B. (2007). Corporate Governance Practices at Higher Education Institutions in South Africa. Journal of Economic and Financial Sciences, 1(2), pp. 105-122.

Marx, B. \& Van der Watt, A. (2013). Sustainability in accounting education: An analysis of the teaching thereof at accredited South African universities. SA Journal of Accounting Research. (In publication, SAJAR, 27 (2013)).

Marx, B. \& Van Dyk, V. (2011). Sustainability reporting at large listed public sector entities in South Africa. SA Journal of Accounting Research, 23(1), pp. 103 -127.

McKenzie, P \& Wurzburg, G. (1997). Lifelong learning and employability. OECD Observer, 209, pp.1318.

Ministry of Education. (MoE). (2009). Ministerial statement on higher education funding:2006/7 to 2008/9. [Online] Available:

http://www.dhet.gov.za/LinkClick.aspx?fileticket=1pKcrKHM4Kw\%3d\&tabid=417\& mid=1221.

(Accessed 13 April 2011).

Moir, J. (2011). Graduate attributes, personalisation and citizenship. $6^{\text {th }}$ Global Conference on Pluralism, Inclusion \& Citizenship. Prague, 10-13 March. 
Morse, J. M. \& Niehaus, L. (2009). Mixed method design principles and procedures. California, USA: Left Coast Press, Inc.

Nisbet, R. (1971). The Degradation of the Academic Dogma. New York: Basic Books, Inc.

PricewaterhouseCoopers. (PWC). (2009). King's Counsel: King III- a higher education perspective. Corporate Governance Series. South Africa.

Priddy, S. \& Bailey, S. (June 2011). The rise of the carbon native. Accounting and Business, pp. 38-39.

South African Graduate Recruiters Association. (SAGRA). (2012a). The SAGRA Candidate Survey 2012. High Flyers Research. South Africa.

South African Graduate Recruiters Association. (SAGRA). (2012b). The SAGRA Employer Survey 2012. High Flyers Research. South Africa.

Smit, R. (2012). Towards a clearer understanding of disadvantage: problematic deficit thinking. Higher Education \& Research Development, 31(3), pp. 369-380.

Smout, M \& Stephenson, S. (2002). Quality Assurance in South African Higher Education: a new beginning. Quality in Higher Education, 8(2), pp. 197-206.

South African Institute of Chartered Accountants. (SAICA). (2010). Competency Framework Detailed Guidance for Academic Programmes. Kengray, Johannesburg. South Africa.

South African Institute of Chartered Accountants. (SAICA). (2012). mandio@saica.co.za. April 2012. List of SAICA accredited universities. Email to benm@uj.ac.za.

University of Johannesburg. (UJ). (2008). UJ Teaching and Learning Strategy. Document approved by Senate, 26 November. Document SEN 252/2008(5).

Walters, S. (2006). Adult learning within lifelong learning: a different lens, a different light. Journal of Education, 39(1), pp. 6-26.

Walters, S. (2010). New Challenges and Opportunities for Lifelong Learning in South Africa. lifelong learning: a different lens, a different light. Comparative Education, 35(2), pp. 217-224.

Wessels, P.L. \& Roos, A. (2009). The Development of a Conceptual Framework for the Design, Delivery and Assessment of a Typical Management Accounting Syllabus. Accounting Perspectives, 8(2), pp. 147-164.

Wright, S.A. (2009). Sustainability, Internationalization and Higher Education. New Directions for Teaching and Learning, no 118. Wiley Periodicals Inc. Wiley Interscience (www.interscience.willey.com). 